Cinfiubrumg in ben Megiftraturbienft.

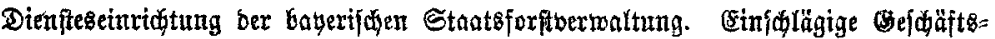
anwetijungen und Dienftesyorjdyriften.

Bemertungen.

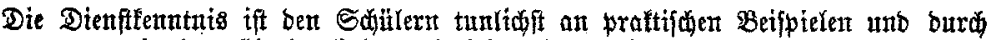

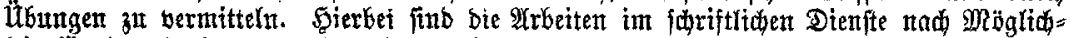
feit fitr ben laufenbent forftomtidien Dienft nubbar zt madien. Die Sditer ber 4. Rlafie

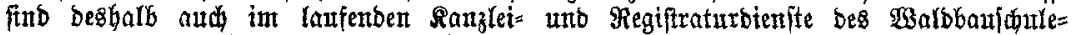

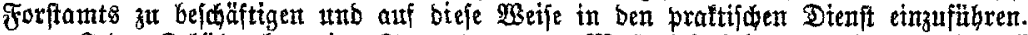

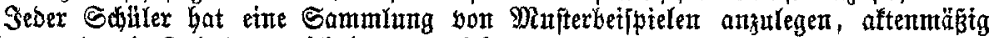

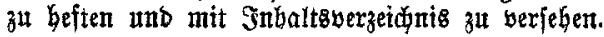

\title{
Perional= Laahridit.
}

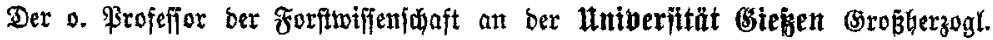

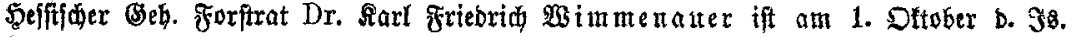
in ben $\Re$ ubeftanb getreten. 